\title{
MÁTYÁS SZABOLCS
}

\section{A településszerkezet és a bünözés összefüggései ${ }^{1}$ a magyar fôváros példáján}

\begin{abstract}
A bünözés vizsgálata során sajnos a geográfiai tényezők relatíve kis súllyal esnek latba, holott számos esetben a bünözés alapokai között lehet keresni az egyes társadalomföldrajzi tényezőket, amire már számos kutatás rávilágított. ${ }^{2}$ A településszerkezet vizsgálata és a bünözés kapcsán pedig mindenképp meg kell említeni a településfejlesztést (amely a társadalomföldrajz egyik rokontudománya), mint olyan területet, amely érdemben tehetne a bünözés csökkentése érdekében. Egyik ilyen, a Magyarországon ez idáig a gyakorlatban nem alkalmazott eljárás az építészeti bünmegelőzés, amely a településfejlesztési politika egyik fontos eszköze lehet a bünalkalmak csökkentésére.

A kutatás során a következő kérdésekre kívántam választ kapni: Milyen kriminalitási különbségek figyelhetök meg az egyes városrészek esetében, $\mathrm{s}$ megfigyelhető-e markáns különbség a városfejlődés különböző szakaszaiban lévő területek büncselekményi struktúrája között. Vagyis a városfejlődés egyes szakaszai érdemben befolyásolták-e (és jelenleg befolyásolják-e) a büncselekményi struktúrát?
\end{abstract}

\section{Városszerkezet a fövárosban}

A belváros

A belváros rendszerint egy településnek az a része, amely évszázadokkal (olykor évezredekkel) ezelőtt a legkedvezőbb feltételeket kínálta a letelepedésre. A településeknek ez a része volt a legjobban védhető (a központi magterület általában városfallal volt körülvéve), és rendszerint a környezetének átlagánál kevésbé fenyegették a természeti csapások is (például árvíz). Itt ta-

1 A tanulmány a KÖFOP-2.1.2-VEKOP-15-2016-00001 azonosítószámú, A jó kormányzást megalapozó közszolgálat-fejlesztés elnevezésủ kiemelt projekt keretében müködtetett Ludovika Kiemelt Kutatómühelyben, a Nemzeti Közszolgálati Egyetem felkérésére készült.

2 Sallai János - Tihanyi Miklós - Vári Vince - Mátyás Szabolcs: A ,jó rendészet” közpolitikai kapcsolódási lehetőségei. In: Kaiser Tamás (szerk.): A jó állam nagyító alatt: speciális jelentések A-tól V-ig (az adóbürokráciától a versenyképességig). Dialóg Campus Kiadó, Budapest, 2016, 83-121. o. 
lálhatók a legrégibb épületek, $\mathrm{s}$ általában itt a legnagyobb a népsürüség is. Kérdésként vetődhet fel, hogy Budapest esetében milyen területeket tekinthetünk belvárosnak. Elöljáróban érdemes azt megjegyezni, hogy hivatalos lehatárolása nincs a belvárosnak. Más, ha építészeti, és más, ha történelmi aspektusból vizsgáljuk a kérdést. Egyesek szükebben értelmezik a belváros fogalmát, mások pedig tágabban. A tágan értelmezett történelmi belváros mintegy kétezer hektár területet foglal el a több mint ötvenkétezer hektár területủ városból. Építészeti szemszögböl az UNESCO által világörökségként nyilvántartott területeit tekinthetjük történelmi belvárosnak, amely hat egymástól élesen elkülönülő területegységből tevődik össze (középkori városmag, Lipótváros, Várnegyed és Várszoknya, Gellérthegy-Tabán, Andrássy út és környezete, Városliget). ${ }^{3}$ A köznyelv belvárosnak tekinti a Duna pesti oldala felőli területen elterülö Vörösmarty tér-Deák tér-Múzeum körút-Kálvin tér-Fővám tér által határolt területet. Funkcionálisan és építészeti szempontból is belvárosnak tekinthető még az V., VI., VII. kerület számos területe. Álláspontom szerint a belváros területét nem korlátozhatjuk kizárólag az építészeti vagy a köznyelvi értelemben vett belvárosra. Belvárosi területnek kell tekintenünk a föváros azon részeit is, amelyek valamely alközpontjának a központi részét alkotják. Ilyen értelemben Kőbánya, Újpest stb. központi területei szintén belvárosnak tekinthetők. ${ }^{4}$

A történelmi belvárosról általánosságban kijelenthetjük, hogy számos nagyvárosunkban még mindig nagy számban vannak leromlott állagú épületek. E területeket rendszerint a városi átlagnál jóval nagyobb bünözési fertőzöttség jellemzi.

A vonzó és taszító hatások mérésének az egyik legfőbb indikátora a településen belüli migráció nagysága. A hetvenes és nyolcvanas években nagyvárosaink legtöbb belvárosa (így Budapest is) már nem tudta megtartani a magasabb társadalmi státusú embereket, akik így nagy számban költöztek ki a belvárosi területekről. ${ }^{5} \mathrm{~A}$ belvárosok lakóépületének fizikai leromlása a fia-

3 Pálfy Sándor - Benkő Melinda: A BME Urbanisztika Tanszékének városépítészeti állásfoglalása Budapest történelmi belvárosának jövőjéröl. Epiteszforum.hu, 2010. augusztus 2.

http://epiteszforum.hu/a-bme-urbanisztika-tanszekenek-varosepiteszeti-allasfoglalasa-budapesttortenelmi-belvarosanak-jovojerol

4 A várostervezéssel foglalkozó szakemberek is rájöttek arra, hogy a főváros történelmi városközpontja túlsúlyossá vált, ezért a településfejlesztés egyik célja, hogy az alközpontokat tudatosan fejlesszék, a városszerkezetben betöltött erejüket növeljék, ezáltal többközpontúvá válhat a város. Budapest Föváros Településszerkezeti Terve, 21. o.

5 Budapest városfejlesztési koncepciója (helyzetelemzés) 4. Budapest társadalma. 2011, 3. 0. http://budapest.hu/Documents/varosfejlesztesi_koncepcio_2011dec/04_Tarsadalma.pdf 
talabb, gazdaságilag aktívabb lakosságot elmozdította az új építésű, házgyári technológiával készült lakótelepek irányába. Ez a szuburbanizációs folyamat volt az, ami jórészt „megalapozta” a jelenlegi kiemelkedő bünözési fertőzöttséget és a büncselekményi struktúrát, mivel ez adott lehetőséget arra, hogy a kiköltözők helyére a társadalmi nívó alacsonyabb szintjén álló lakók költözzenek be. Örvendetes tény azonban, hogy az elmúlt egy évtizedben felgyorsult a településeink belvárosainak tömbrehabilitációja, ennek hatására megtörtént számos belvárosi épület rekonstrukciója, illetve a belvárosi lakások ideiglenes vagy jogtalan bérlöinek a kiköltöztetése, beindítva ezzel a belvárosok népességének átstrukturálódását (reurbanizáció). Ennek következtében számos helyen csökkent a büncselekmények száma, illetve strukturális változások is bekövetkeztek (például a Józsefvárosban lévő Corvin negyed).

A főváros belvárosi részeinek esetében a rehabilitációs folyamatokat az ezredforduló környékén részben az üzleti tőke indította be. A kiemelkedő müszaki színvonalú lakások és irodaházak presztízst adtak a területnek. Ennek eredményeképp néhány éven belül felgyorsult a fiatalok visszaáramlása, és megkezdődött a lakosság átstrukturálódása. Mindezzel a folyamattal párhuzamosan viszont az agglomeráció településein kínálati lakáspiac alakult ki, elsősorban a nagy területü ingatlanok esetében. ${ }^{6}$

A belváros ${ }^{7}$ - mint a települések pénzügyi, közigazgatási, kulturális, idegenforgalmi és üzleti negyede - büncselekményektől az egyik leginkább érintett terület, ahol a tipikus városi büncselekményeknek rendszerint szinte minden típusa megtalálható, a zsebtolvajlástól a fegyveres rablásig (táblázat).

A belváros és a belső, városias lakóövezet területén figyelhetők meg elsősorban a szegregátumok (krízisterületek). Ezekkel kapcsolatban megállapíthatjuk, hogy összefüggő, nagy kiterjedésü szegregátumok nem alakultak ki a főváros területén, és a már meglévők is meglehetősen diffúz módon helyezkednek el. Elsősorban a pesti oldal belső kerületeiben fedezhetők fel ilyen területek, a VII., VIII., IX., XIII., X., XVII. és XXI. kerületekben legalább két krízisterület, míg a III., XVIII. és XIX. kerületekben pedig egy krízisterület található (ábra). ${ }^{8}$

6 Uo. 27. o.

7 A Burgess-modell szerint a belvárosi rész tekinthető a citynek (vagy a CBD-nek), illetve Mendöl Tibor klasszikusnak számító településszerkezeti felosztásában a belsö munkahelyi övnek. Mendöl Tibor: Általános településföldrajz I. ELTE, Budapest, 1957

8 Budapest 2030. Hosszú távú városfejlesztési koncepció. Budapest Főváros Városépítési Kft., Budapest, 2014, 103. o. 


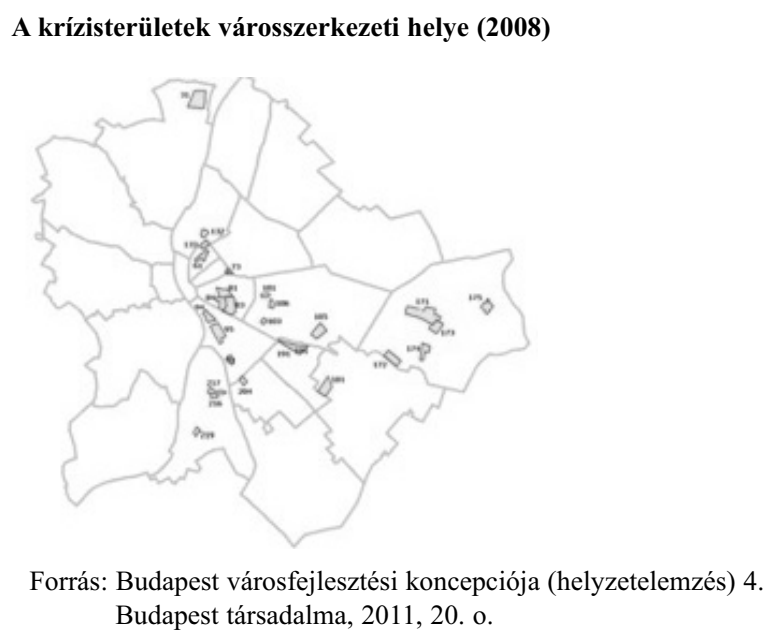

A tágabban értelmezett belváros esetében számos helyen erős dichotómia figyelhető meg. Jó példa erre a főváros VIII. kerülete. A VIII. kerület része a korábban elit területnek számító Palotanegyed, amelynek tömbrehabilitációja folyamatos, illetve a szintén a kerületben lévő józsefvárosi terület, amelyet évtizedek óta a város legrosszabb lakóterületei között tartanak számon. Meg kell természetesen jegyezni, hogy Józsefváros számos területén megkezdődött a rehabilitáció (például Magdolna-negyed, Corvin-Szigony-projekt), azonban még ennek ellenére is egy kerületen belül jelentősen eltérő bünözési fertőzöttséget lehet regisztrálni, amely látványosan megjelenik a VIII. kerületi bünözési térképén is. ${ }^{9}$

A tanulmánynak nem célja kriminálprognosztika készítése, azonban a szerző véleménye szerint előrevetíthető az, hogy az egyre inkább előrehaladó rehabilitációs (városrekonstrukciós) munkálatok olyan jelentős lakosságcserét idéznek elö, amelyek következtében csökkeni fog a terület bünözési fertőzöttsége. A reurbanizációs folyamat azonban csak látszólag oldja meg a problémát, mivel ezzel csak áthelyezik a problémás családokat. A lakosság kiköltöztetése ezért nem jelenthet végleges megoldást, mivel csak a rehabilitált terület helyzete javul, a fogadó területé nem. A végleges megoldást csak a szegregált területek fizikai és szociális rehabilitációja jelentheti.

9 Budapest városfejlesztési koncepciója (helyzetelemzés) 4. Budapest társadalma. 2011, 5. o. 
A történelmi magot egy kiugró lakósürüségü és erős lakóhely funkciójú belső, városias lakóövezet veszi körül. Nézzük meg, hogy a fôváros esetében milyen területek sorolhatók ide! A terület egzakt lehatárolása nem egyszerü, mivel mindenki által elfogadhatóan még a belváros lehatárolása sem lehetséges, így nehéz pontosan azt megmondani, hogy melyek azok a területek, amelyek övezik. A vidéki nagyvárosaink esetében ez többségében az egy-két emeletes, a fóváros esetében pedig a két-három emeletes lakóházak övezetét jelenti. Természetesen érdemes különbséget tenni a történelmi belváros és a városon belül található városközpontok között (például V. kerület $\leftrightarrow$ Kőbánya). Előbbi esetében általában egy-két szinttel magasabbak az övezet házai, és a kiterjedésük is rendszerint terebélyesebb.

A főváros településszerkezeti tervének értelmében a belső városrészek esetében (így a belső, városias lakóövezetben is) várhatóan a következő években a jelenleginél is nagyobb volumenü komplex rehabilitáció valósul meg, nagyobb részben a közösségi és a magánszektor összehangolt akciói nyomán. ${ }^{10}$ Ez várhatóan pozitív hatással lesz a büncselekményi fertőzöttség alakulására is. Nemcsak a történelmi belvárosban kezdődnek (kezdődtek) tehát rehabilitációs munkálatok, hanem az alközpontokban is (például Köbánya). ${ }^{11}$

Általánosságban elmondható, hogy a zónában a lakófunkció dominál, a kereskedelmi és egyéb funkció szerepe elhanyagolható a belvároshoz képest. Ennek következtében számos esetben a slumosodás elörehaladottabb, mivel nincs meg az a főként kereskedelmi szektor által hajtott mozgató erő, ami az ingatlanok állagára pozitív hatással lenne. A városias lakóövezetben jóval kisebb léptékủ a tömbrehabilitáció és a lakónépesség átstrukturálódása, a reurbanizációs folyamatok pedig lassabban haladnak, mint a belvárosi területeken.

A terület jellegéből és funkciójából adódóan a belvárost övező utcákon a leginkább jellemző bűncselekménytípusok az autófeltörés, a betöréses lopás, a rablás, a graffiti jellegü rongálás és a házalásos csalás. ${ }^{12}$

\footnotetext{
10 Budapest Főváros Településszerkezeti... i. m. 15. o.

11 Egedy Tamás - Kovács Zoltán - Székely Gáborné - Szemző Hanna: Fővárosi rehabilitációs programok és eredmények. In: Egedy Tamás (szerk.): Városrehabilitáció és társadalom. Tanulmánykötet. MTA FKI, Budapest, 2005, 178-180. o.

http://www.varosrehabilitacio.net/media/files/Varosrehabilitacio/varosrehabestarsadalomcikkek/ 7Egedyetal_cikk.pdf

12 A Burgess-modell alapján a belső, városias lakóövezet az átmeneti zónának felel meg, míg Mendöl Tibor belsö lakhelyi övnek nevezte a területet. Mendöl Tibor: i. m.
} 
A belső lakóhelyövet egy relatíve alacsony lakósürüségü, családi házas, kertvárosi övezet veszi körül. E területek között azonban igen jelentős eltérések figyelhetők meg a lakosság korstruktúrája, életmódja, jövedelmi viszonyai, elkövetési módok, büncselekményi típusok, eltulajdonított tárgyak stb. tekintetében.

Az újonnan vagy egy-két évtizeddel ezelött épült családi házas területek esetében a betöréses lopások során főként a kerti bútorok, a nagyobb értékủ kutyák, az értékesebb kerti szerszámok, illetve az épülő ingatlanok esetében az építőanyag és az épületgépészeti berendezések az elkövetés tárgyai ${ }^{13}$ (például Helikopter-lakópark), míg a régebbi építésü, falusias jellegü városrészeknél (Kispest, Csepel) a melléképületekben tárolt gépi berendezések és kerti szerszámok (egyre ritkábban bár, de napjainkban is előfordul még, hogy szárnyas jószágok az elkövetés tárgyai). A régebbi építésü területek esetében a lakosság jórészt az idősebb korosztályokból kerül ki. Esetükben az életkor okozta kiszolgáltatottság és jóhiszemüség következtében gyakoribbak a megtévesztéssel elkövetett lopások, illetve a csalások bizonyos formái (csatorna- és tetőfelújítás, áruvásárlás, például tűzifa-, edény- stb.). ${ }^{14}$ Éles különbségek fedezhetők fel a vagyonvédelem szempontjából is. Míg az újonnan épített területeken gyakran kamerarendszerek és riasztóberendezések működnek, addig a régebbi építésü területeken sokszor a vagyonvédelem legelemibb feltételei is hiányoznak. ${ }^{15}$

\section{Lakótelepek övezete}

Az urbanizáció szónak a magyar nyelvben két jelentése van, az egyik a település minőségi gyarapodását (városiasodás), míg a másik a mennyiségi gyarapodását jelenti (városodás). A lakótelepek esetében megállapítható, hogy egyaránt volt minőségi és mennyiségi fejlődés is, azonban a lakáspolitika különösen a hatvanas és hetvenes években föként a mennyiségi gyarapodásra helyezte a hangsúlyt, amelynek negatív hatásai a mai napig kimutathatók.

\footnotetext{
13 Országos szinten az 1990-es évektől kezdődően érte el hazánkat az a már Észak-Amerikában és Nyugat-Európában korábban ismert jelenség, hogy a városok szélén, a beépítetlen területeken külön városrészek (lakóparkok) jöttek létre. Ezeken a helyeken a városi átlag feletti komforttal és minőséggel jellemezhető kertes és emeletes házak épültek, ahová elsősorban a tehetősebb értelmiségiek költöztek. 14 Semmiképp sem szabad a régebbi építésű, családi házas területeket egy típusként kezelni, mivel vannak olyan fővárosi területek, amelyek bár régebbi építésűek, de emelkedő státusúak, és mára kifejezetten magas ingatlanárak jellemzik. Az elmúlt egy-másfél évtizedben jelentős lakosságcsere is bekövetkezett a területükön (például Wekerle-telep).

15 Mátyás Szabolcs: Bűnözésföldrajz. Megjelenés alatt.
} 
Nagyvárosaink többségében vannak kisebb-nagyobb kiterjedésủ lakótelepek. Mint említettem, lakónépességük egy része a településen belüli migrációból származik (belvárosból és a külső övezetekből), míg másik része a rurális térségekből és a környező településekről származó vándorlásból. Ennek nyomán a lakótelepeken rendkívül heterogén populáció jött létre, ami számos szociológiai és kriminológiai problémát okozott, $\mathrm{s}$ jelenleg is megoldatlan gondok forrása. A nagyvárosi bünözés számos vonása fedezhető fel; a legjellemzőbb deliktumtípusok a gépkocsi-, pince- és lakásfeltörés, a rongálás (például graffiti, tömegközlekedési eszközök váróinak megrongálása), a kábítószerrel kapcsolatos büncselekmények és a rablás. ${ }^{16}$

Hazánk legnagyobb öt lakótelepe a fővárosban található, népességük akár egy megyeszékhely lakosságát is meghaladhatja. ${ }^{17}$ Mindenképp megemlítendő Budapest esetében az a tény, hogy az egyes lakótelepek között igen nagy különbségek figyelhetök meg, a lakosság összetétele, a szociológiai helyzete stb. tekintetében, aminek természetesen jelentős bünügyi relevanciája is van. Gondolhatunk például a Havanna lakótelepre és a Gazdagréti lakótelepre, amelyek gyökeresen eltérő karakterisztikájú részei a fővárosnak.

Falusias, tanyasias jellegü övezet

A legtöbb nagyvárosunknál megfigyelhető, hogy a családi házas (kertvárosi) övezet után egy jóval lazább beépítésủ és alacsonyabb lakósürüségü, nagy kiterjedésü öv, a falusias/tanyasias övezet következik. Ez föként zártkerteket, szőlőskerteket, hétvégi házakat és tanyavilágot foglal magában. E területen a rendszerváltozás előtt zömmel a középosztályhoz sorolható polgárok hétvégi kertjei voltak, így az állandó népessége csekély volt. A rendszerváltozás után a változásokat vesztesként megélők közül sokan a városi lakásukat eladva, az olcsóbb megélhetés reményében itt vásároltak maguknak ingatlant. A kertségi részek lakosságának másik csoportját a belvárosi területekröl kiköltözők alkotják. E területek így megsokszorozták állandó lakónépességüket, létrehozva egy sajátos, a vagyonbiztonság szempontjából kritikus szubkultúrát.

16 A lakótelepek, a kertségi és egyéb kiterjedt lakófunkciójú területek a Mendöl-féle felosztás alapján a külső lakóhelyi övként értelmezhetők. A Mendöl Tibor által ipari zónaként leírt, alacsony lakófunkciójú külső munkahelyi öv viszont mára sok helyen megszünt (részben az ipari létesítmények bezárása következtében), illetve jelentősen átalakult (logisztikai központok, raktárak stb.). Mátyás Szabolcs: i. m.

17 A KSH 2011-es felmérése alapján a legnagyobb fővárosi lakótelep a Füredi utcai lakótelep (58 386 fö), a kelenföldi városközpont (52 474), a rákospalotai lakótelep (38 530), az óbudai lakótelep (36 835) és az óbuda-békásmegyeri lakótelep (34 418).

http://www.ksh.hu/apps/hntr.telepules?p_lang=HU\&p_id=13578 
A marginalizálódott kiköltözők közül sokan az évek alatt sem találtak munkát és jelenleg is a környéken elkövetett kisebb súlyú büncselekményekből tartják el magukat. ,A bünelkövetök a ház- és melléképület-feltörések alkalmával föként kerti gépeket, szerszámokat, szárnyasokat és egyéb haszonállatokat (pl.

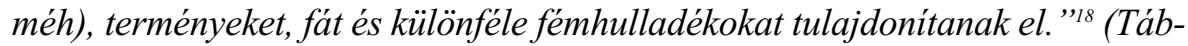
lázat.)

Az egyes településrészekre jellemző főbb bűncselekménytípusok

\begin{tabular}{|l|l|}
\hline Településrész megnevezése & Jellemző büncselekmény-típusok \\
\hline belváros & $\begin{array}{l}\text { zseblopás, gépkocsifeltörés, rablás, pénzintézetek sérelmére elkövetett } \\
\text { fegyveres rablás, kerékpárlopás, rongálás, garázdaság } \\
\text { belsóp lakóhelyi öv }\end{array}$ \\
$\begin{array}{l}\text { kertvárosi övezet } \\
\text { betöréses lopás, megtévesztéssel elkövetett csalások } \\
\text { lakótelep }\end{array}$ & $\begin{array}{l}\text { gépkocsi- és kerékpárlopás, pincefeltörés, lakásbetörés, rongálás, rablás } \\
\text { betöréses lopás, állat- és terménylopás }\end{array}$ \\
zártkert/tanyavilág & lakásbetörés, állatlopás, házalással elkövetett csalás \\
\hline
\end{tabular}

Budapest esetében megállapíthatjuk, hogy a tanyasias jellegü övezet gyakorlatilag teljesen hiányzik. Részint azért, mivel a várost gyürüszerüen körbevevő települések fizikailag akadályozzák a város ilyen irányú terjeszkedését, a laza szerkezetü tanyasias övezet kialakulását. A hétvégi házas övezet megfigyelhető számos kerületben (például II., III., XI., XII., XVII., XXI., XXII., XXIII.), azonban ezek esetében olyan mértékủ szegregáció, mint ami a falusias, tanyasias jellegü övezetnél megfigyelhető, nem jellemző. Ennek az oka részben az, hogy e területek esetében a relatíve magas ingatlanár nem tette lehetővé a marginális helyzetü csoportok beköltözését ${ }^{19}$, így e területek vagyonbiztonságában nem következett be negatív előjelü fordulat. Másrészt pedig megfigyelhető az a tendencia is, hogy a főváros még be nem épített, falusiasnak nevezhető területei fokozatosan beépülnek. Példaként hozhatjuk fel például a Széchenyihegyet és környékét, ahol néhány évtizeddel ezelött még többségében beépítetlen, parlag területek voltak, napjainkra azonban elvétve találni beépítetlen földterületet. A vagyonbiztonság szempontjából tehát jóval kedvezőbb helyzetben vannak jelenleg is e fővárosi periferikus területek, más vidéki nagyvárosaink hétvégi házas övezeteihez képest.

\footnotetext{
18 Mátyás Szabolcs: i. m.

19 A relatíve magas ingatlanárakat mutatja, hogy a tanulmány írásának idején (2016. november) az Ingatlanbazár.hu honlapon a legolcsóbb hétvégi ház ötmillió-egyszázezer forintba került. Ezt az ár többszöröse egy Debrecen vagy Miskolc környéki klasszikus, úgynevezett víkendház árának.
} 
A város zöldterületeinek megőrzése a fővárosi fejlesztési koncepció egyik kiemelten kezelt eleme. A város körüli ,zöld gyürü” a záloga annak, hogy a várostest és az agglomeráció települései fizikai értelemben is összenőjenek. Ez tekinthető a nagytérségi rekreáció tervezett területeinek is. Ez alapján valószínüsíthető, hogy a főváros külső részein lévő zöld területek nem esnek áldozatul a városfejlődésnek. ${ }^{20}$

\section{Szuburbanizációs övezet (agglomerációs gyürü)}

Ha a városszerkezetet tanulmányozzuk, semmiképp sem hagyhatjuk ki a szuburbanizációs övezet vizsgálatát. E települések rendszerint az ,anyatelepüléstől" nagyjából tíz-tizenöt kilométer sugarú körben helyezkednek el. Budapest esetében megállapíthatjuk, hogy sem közigazgatásilag, sem a Budapesti Rendőr-fökapitányság illetékességi területéhez nem tartoznak az agglomerációs települések, azonban szoros szimbiózisban élnek a várossal. A főváros esetében a nagyjából tíz-tizenöt kilométer sugarú körnél jóval szélesebb a szuburbanizációs övezet, elérheti akár a negyven-ötven kilométert is. Ez részben a jól kiépített vonalas infrastruktúrának köszönhető (autópálya, gyorsforgalmi út, HÉV, vasút), ami nagyban csökkenti a fövárosba történő utazási időt.

Az agglomerációs gyürü bővülésével, szélesedésével differenciálódnak a környező területek. Szétválnak az egyes funkciók (lakó, kereskedelmi, ipari stb.), és egyre szaporodnak azok a helyek, amelyek szinte kizárólag csak gépkocsival közelíthetők meg $^{21}$. A differenciálódás az élet szinte minden területén megjelenik. Az agglomerációs területeken az odaköltöző családok miatt növekszik a sérthető értékek aránya (ingatlan és ingó tárgyak egyaránt), így új forró pontok jelenhetnek meg a főváros környéki területeken. A nagyszámú népességkiáramlás számos bevásárlóközpontot és egyéb kereskedelmi egységet hívott életre, amelyek mindegyike bünelkövetés helyszíne lehet.

A szuburbanizáció jelenségének egyik motorja a települések közötti vonalas infrastruktúra kiépülése és fejlődése, a térbeli elérhetőség javulása. Ez teszi ugyanis lehetővé azt, hogy viszonylag gyorsan lehessen eljutni az agglomeráció valamely településéről a központi településre. Ha ez megoldott, akkor jelentősen nő a központi városból kiköltözők száma. Ez azonban nem csak a törvénytisztelő állampolgárok számára vonzó tényező. A bűnelköve-

\footnotetext{
20 Budapest Főváros Településszerkezeti... i. m. 24. o.

21 Kiss Gabriella Katalin: Budapesti szuburbanizációs folyamatok hatása a hulladékgazdálkodásra. Corvinus Egyetem Környezetgazdaságtani és Technológiai Tanszék, Budapest, 2013. http://phd.lib.uni-corvinus.hu/834/2/Kiss Gabriella thu.pdf
} 
tők életében is a közgazdasági törvényszerüségek uralkodnak. Hogyha javul egy település megközelíthetősége, az mindenképp ,pozitívan” hat a bünelkövetők számára is, és növeli a bünelkövetői vonzáskörzet nagyságát. ${ }^{22}$ A szuburbanizációs folyamatok hatására számos ,alvó település” jött létre (különösen új építésű lakóparkok esetében), ahová tulajdonosaik szó szerint csak aludni járnak haza, így a napközbeni népességük meglehetősen csekély, ami ideális feltételeket teremt a büncselekmények elkövetéséhez.

A fővárosban a szuburbanizációs folyamatok a korábbi sugaras elhelyezkedésü közlekedési infrastruktúrát, haránt jellegü közlekedési elemekkel egészítették ki, ami mindenképp kedvezően hatott a város tehermentesítésére és a térbeli diffúzióra. ${ }^{23} \mathrm{~A}$ nyilvánvaló pozitív hatások mellett azonban meg kell jegyezni, hogy ez hozzájárult a fővárosi bünelkövetők müködési területének a kiterjedéséhez is.

\section{Összegzés}

A tanulmány a főváros példáján keresztül bemutatta a településszerkezet és a bünözés közötti szoros kapcsolatot. Megállapította, hogy a városfejlödés egyes szakaszai mennyire jelentősen befolyásolják a büncselekmények terjedelmének változását. Budapest városfejlesztési koncepciójának ismeretében prognosztizáltam a belvárosi területek fizikai és szociális rehabilitációját, a büncselekmények számának csökkenését, a büncselekményi struktúra változását. Szintén elöre jelezhető a szuburbanizációs övezet lakosságának csökkenése, ami feltételezhetően a fővárosközeli területeken a büncselekmények számának csökkenéséhez is vezet.

\section{IRODALOM}

Bujdosó, Zoltán - Dávid, Lóránt - Tenk, András: Utilization of Geoheritage in Tourism Development. Procedia - Social and Behavioral Sciences, vol. 188, 2015, pp. 316-324.

Egedy Tamás - Kovács Zoltán - Székely Gáborné - Szemző Hanna: Fővárosi rehabilitációs programok és eredmények. In: Egedy Tamás (szerk.): Városrehabilitáció és társadalom. Tanulmánykötet. MTA FKI, Budapest, 2005, 178-180. o.

http://www.varosrehabilitacio.net/media/files/Varosrehabilitacio/varosrehabestarsadalomcikkek/7Egedyetal_cikk.pdf

\footnotetext{
22 Lásd bővebben Mátyás Szabolcs: A Debreceni Rendőrkapitányság elkövetői és bủnelkövetői vonzáskörzete. Magyar Rendészet, 2012/2., 49. o.

23 Budapest városfejlesztési koncepciója (helyzetelemzés) 4. Budapest társadalma. 2011, 28. o.
} 
Kiss Gabriella: Budapesti szuburbanizációs folyamatok hatása a hulladékgazdálkodásra. Fiatal Regionalisták IV. országos Konferenciája, Győr, 2004

Mátyás Szabolcs: A Debreceni Rendőrkapitányság elkövetői és bünelkövetői vonzáskörzete. Magyar Rendészet, 2012/2.

Mátyás Szabolcs - Sallai János - Tihanyi Miklós - Vári Vince: A ,jó rendészet” közpolitikai kapcsolódási lehetőségei. In: Kaiser Tamás (szerk.): A jó állam nagyító alatt: speciális jelentések A-tól V-ig (az adóbürokráciától a versenyképességig). Dialóg Campus Kiadó, Budapest, 2016, 83-121. o.

Mátyás Szabolcs: Bűnözésföldrajz. Egyetemi jegyzet. Megjelenés alatt

Mendöl Tibor: Általános településföldrajz I. ELTE, Budapest, 1957

Pálfy Sándor - Benkő Melinda: A BME Urbanisztika Tanszékének városépítészeti állásfoglalása Budapest történelmi belvárosának jövőjéről. Epiteszforum.hu, 2010. augusztus 2. http://epiteszforum.hu/a-bme-urbanisztika-tanszekenek-varosepiteszeti-allasfoglalasabudapest-tortenelmi-belvarosanak-jovojerol 